\title{
11 Adding value from marketing origin of food from the Arctic Norway
}

\author{
Bjørg Helen Nøstvold, Ingrid Kvalvik, \\ \& Morten Heide
}

\section{Introduction}

The Norwegian Arctic is important as a food-producing region, producing food from both marine and terrestrial resources. Fisheries, aquaculture, agriculture (both meat and vegetables) and reindeer herding, and processing of these products are important for sustaining the economy, population, and culture in many local communities. Within Arctic Norway, there is considerable variation in products and markets. Fisheries and aquaculture are large-scale and export-oriented, but also include a high number of companies producing for the local and national market. Agriculture is quite marginal compared to farming in more favorable locations further south but produce both for the big national cooperatives and for smaller companies. All food sectors are producing both commodities and high-value niche products for local, regional, and national markets.

Natural conditions like harsh weather and cold climate, combined with a high general cost level in Norway makes it impossible to compete with low cost, high volume, mass-produced products from lower cost countries. Hence, agriculture is heavily subsidised, and it is a public debate that too much seafood is exported unprocessed as a result of high production costs in Norway (Iversen et al., 2016). At the same time, there is a growing market for authentic and niche food products. According to Luceri, Latusi, and Zerbini (2016), emphasising the geographic origin of a product is one way of ensuring authenticity, quality, and food safety to consumers, and hence, a potential marketing strategy for added value for producers. In an Arctic context then, a very relevant question is whether there is a potential for attaining added value by exploiting the image of the Arctic region in marketing of food products. Studies by van Ittersum, Candel, and Meulenberg (2003) and Kuznesof, Tregear, and Moxey (1997) show that a condition for region of origin branding to positively influence consumers' perception of food products is that the product and its qualities coincide with what the consumer associate and perceives as authentic for the region. Successful use of Arctic origin in the branding of food products from the Arctic requires knowledge about what consumers perceive as "authentic Arctic food products" and the 


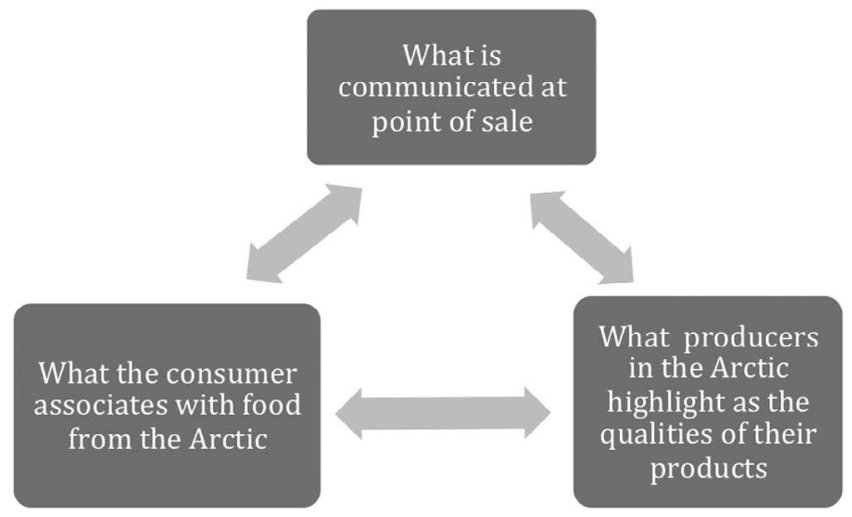

Figure 11.1 Consumer and producer perceptions, and the marketing of Arctic food.

characteristics of such products. In this study, we examine Norwegian consumers' perceptions of Arctic food because it is reasonable to assume that the perception of consumers within the Arctic region differs from that of the consumers outside the region. Consequently, the marketing strategies might need to be different if you target a local/regional market or a market outside the region. The consumers are therefore split into two groups: local consumers, that are consumers who live within the Arctic region themselves, and consumers from the southeastern part of Norway around the capital where the population density is the highest. Knowledge about consumer preferences can provide input about targeted marketing, which can increase sales and added value of Arctic food products. To complement the analysis, we also examine the producers' view of their own products and to what degree and how they take advantage of "Arctic qualities" and the Arctic origin in their marketing. By doing this, the study reveals to what degree producers' marketing strategies correspond with the consumers' perception of Arctic food, illustrated in Figure 11.1. Based on this, we discuss the potential for adding value by exploiting the Arctic origin in the marketing of food from Norwegian Arctic, in the region and outside the region.

\section{Background: Artic Norway - geographical, cultural, and economic setting}

With a total mainland area of $324,000 \mathrm{~km}^{2}$ and 5.3 million inhabitants, Norway is one of the least densely populated countries in Europe. The built-up area, including roads, amounts to only about $2 \%$, and a further $3 \%$ is cultivated agricultural land. Norway has a $2,500 \mathrm{~km}$ coastline, with $90,000 \mathrm{~km}^{2}$ of sea within the baseline and an exclusive economic zone of $788,000 \mathrm{~km}^{2}$ of the mainland, providing plenty of suitable space for aquaculture production and good fishing grounds. In addition, the zone outside the Svalbard archipelago is important for fishing (see Figure 11.2). 


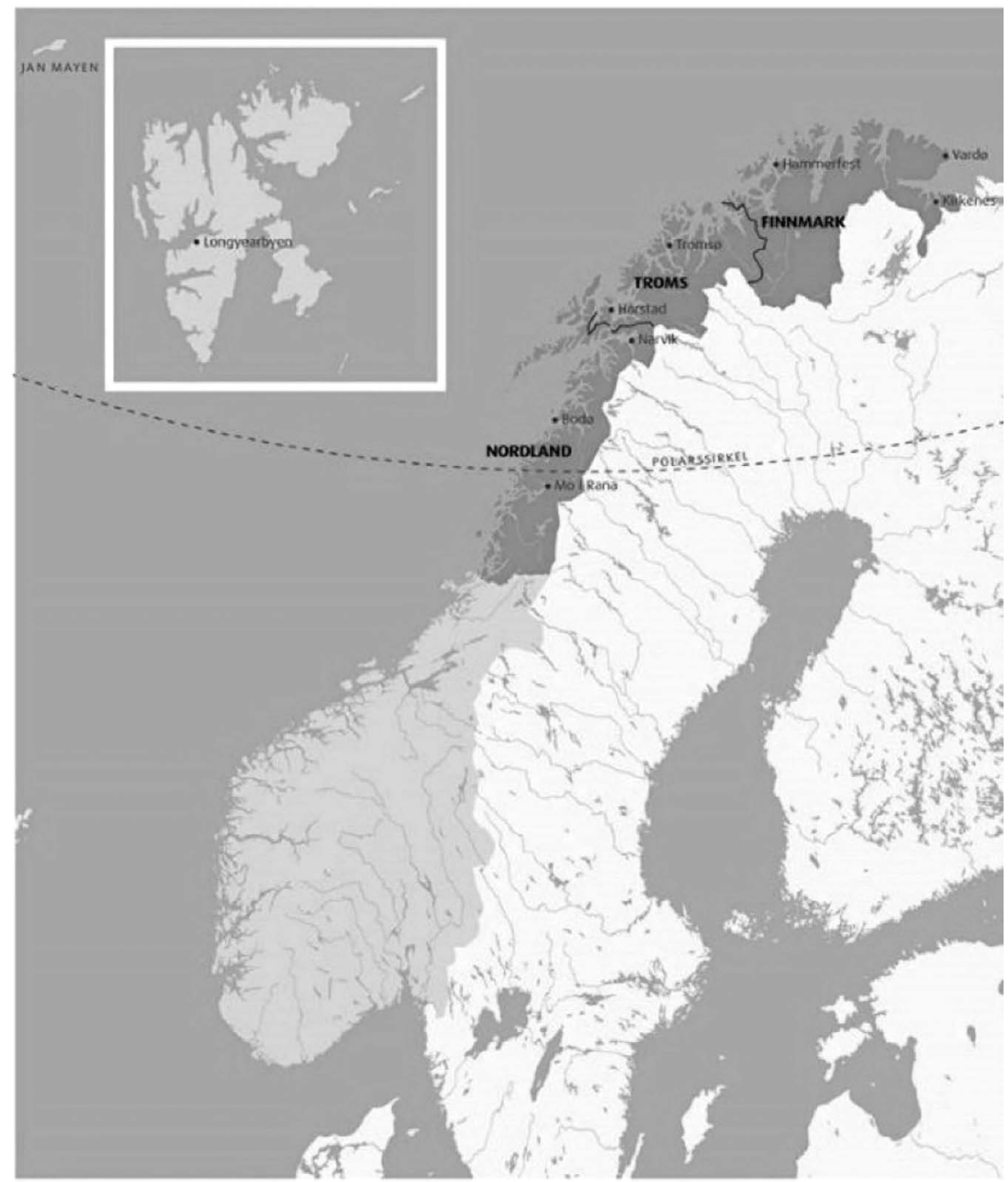

Figure 11.2 Arctic Norway.

Based on climatic parameters only a tiny fraction of mainland Norway is in the Arctic. If defined by the Arctic Circle (located at a latitude of $66^{\circ} 33^{\prime}$ North), about half of Norway is however considered the Arctic. This includes the two northernmost counties (Troms and Finnmark) and approximately half of the third northernmost county (Nordland). Politically, however, all the three counties are considered part of Arctic Norway or Northern Norway, and the Norwegian High North policy is directed at all three counties (in addition to Svalbard, the archipelago in the Barents Sea between $74^{\circ}$ and $81^{\circ}$ North, which have a small population involved in mining, research, and tourism). Similarly, food policies directed at the three northernmost 
counties (Nordland, Troms, and Finnmark) are termed Arctic agriculture (Anon., 2011a, 2016). The area covers more than one-third of the land area $\left(113,000 \mathrm{~km}^{2}\right)$ and more than half of the coastline, but only $9 \%$ of the population (486,000 persons). Arctic Norway is therefore characterised by scattered settlements and long distances.

There are two bigger cities (in a Norwegian context Tromsø and Bodø, with 75,000 and 51,000 inhabitants respectively are relatively big cities), four medium-sized cities (Harstad, Alta, Mo i Rana and Narvik, ranging from 25,000 to 20,000 inhabitants), and a good handful of smaller cities in addition to a large number of smaller communities (see Figure 11.2). In addition to the majority population, Norway has a Sami population. The main Sami settlements are in Finnmark, but also in the rest of the region, in addition to some areas further south.

Food production, both land-based and sea-based, is important for settlement in the rural areas in Northern Norway. In addition to several thousand employed in primary harvesting and production, there are more than 600 companies in northern Norway producing food products for local, national, and international consumers (see Table 11.1). On a global scale, even the largest seafood factories and dairies in Arctic Norway are considered SMEs (small- and medium-sized enterprises with less than 250 employees

Table 11.1 Food production in Arctic Norway (in 2016)

\begin{tabular}{|c|c|c|c|c|c|c|}
\hline & Fisheries & Aquaculture & $\begin{array}{l}\text { Meat } \\
\text { (cattle, sheep, and } \\
\text { pigs) }\end{array}$ & Reindeer & $\begin{array}{l}\text { Dairy } \\
\text { products }\end{array}$ & Horticulture \\
\hline $\begin{array}{l}\text { Annual } \\
\text { Production } \\
\text { - Volume } \\
\text { - Value }\end{array}$ & $\begin{array}{l}-354000 \text { tons } \\
-\quad 12 \text { billion } \\
\text { NOK }\end{array}$ & $\begin{array}{l}-511000 \text { tons } \\
-29 \text { billion NOK } \\
\text { (eksport value) }\end{array}$ & $\begin{array}{l}-186000 \text { sheep } \\
-28000 \text { cattle } \\
104000 \text { pigs } \\
-2,15 \text { billion NOK }\end{array}$ & $\begin{array}{l}-82000 \text { animals } \\
-1800 \text { tons meat } \\
-1500 \text { tons by- } \\
\text { products } \\
-500 \text { mill NOK }\end{array}$ & $\begin{array}{l}-151000 \text { mill } \\
\text { litres cow milk } \\
-7 \text { mill litres } \\
\text { goat milk } \\
-1,43 \text { billion } \\
\text { NOK }\end{array}$ & $\begin{array}{l}-8 \quad 400 \text { tons } \\
\text { potatoes, and } \\
\text { some } \\
\text { vegetables } \\
-100 \text { mill NOK }\end{array}$ \\
\hline $\begin{array}{l}\text { Companies } \\
\text { - Primary } \\
\text { 1roduction } \\
\text { - Secondary } \\
\text { production }\end{array}$ & $\begin{array}{l}-97 \text { purchaser } \\
\text { and } \\
\text { producers } \\
\text {-app. } 50 \\
\text { companies } \\
\text { producing for } \\
\text { national } \\
\text { market }\end{array}$ & $\begin{array}{l}-39 \text { companies } \\
\text { dominated by } 4 \\
-35 \text { smaller } \\
\text { companies } \\
\text { producing for } \\
\text { national market }\end{array}$ & $\begin{array}{l}\text {-dominated by } 1 \\
\text { large national } \\
\text { cooperative (with } 3 \\
\text { slaughterhouses), } 1 \\
\text { medium sized and a } \\
\text { few smaller } \\
\text { slaughterhouses } \\
\text { - in addition, } 10 \\
\text { processing } \\
\text { companies and } 60 \\
\text { micro processors }\end{array}$ & $\begin{array}{l}-7 \text { slaughterhouses } \\
-15 \text { processing } \\
\text { companies, } 5 \text { with } \\
95 \% \text { of the market } \\
\text { share }\end{array}$ & 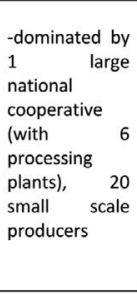 & $\begin{array}{l}\text {-dominated by } \\
1 \text { large national } \\
\text { cooperative, } \\
\text { and one } \\
\text { national and } \\
\text { one local } \\
\text { company. Also } \\
\text { several small } \\
\text { companies } \\
\text { (farm level) }\end{array}$ \\
\hline $\begin{array}{l}\text { Employment } \\
\text { - Direct } \\
\text { - Supporting } \\
\text { inudstries }\end{array}$ & $\begin{array}{l}-4500 \text { fishers } \\
-3 \quad 000 \text { to } \\
7 \quad 000 \text { in } \\
\text { processing } \\
\text { depending on } \\
\text { season }\end{array}$ & $\begin{array}{l}-2200 \\
-5500\end{array}$ & $\begin{array}{l}-3000 \text { farmers } \\
-1000 \text { in processing }\end{array}$ & $\begin{array}{l}-950 \text { reindeer } \\
\text { owners } \\
-350 \text { in slaughter } \\
\text { and processing } \\
\text { companies } \\
\text {-with all processing } \\
\text { companies, app } \\
1000 \text { employees }\end{array}$ & $\begin{array}{l}-1000 \text { farmers } \\
-500 \text { to } 600 \text { in } \\
\text { the processing } \\
\text { industry }\end{array}$ & $\begin{array}{l}-500 \text { farmers } \\
-200 \\
\text { production in } \\
\text { companies, and } \\
\text { seasonal } \\
\text { workers }\end{array}$ \\
\hline Markets & $95 \%$ exported & $95 \%$ exported & $\begin{array}{l}\text { regional and } \\
\text { national market }\end{array}$ & $\begin{array}{l}\text { Mainly sold in the } \\
\text { north, some to } \\
\text { southern Norway }\end{array}$ & $\begin{array}{l}\text { Local, regional } \\
\text { and national } \\
\text { market }\end{array}$ & $\begin{array}{l}\text { HoReCa } \\
\text { important } \\
\text { market for local } \\
\text { and regional } \\
\text { market, also } \\
\text { national }\end{array}$ \\
\hline
\end{tabular}


and annual turnover up to EUR 50 million) (EC, 2016). Still, in a North Norwegian context they are quite large and contribute with significant revenue to the Norwegian national, regional, and local economy. Most companies are however more in the scale of micro to small enterprises (1-50 employees).

The government emphasises the need for increased and sustainable food production and the need to take advantage of national resources (Anon., 2016). It is a government aim to have food production in the whole country. As mentioned, both fisheries and aquaculture are big scale and exportoriented, while agriculture is rather small scale and heavily subsidised. Agricultural production in Norway, and Northern Norway, in particular, is taking place under challenging climatic and geographical conditions, specific programs are therefore created to support it. Increased food production in Arctic Norway is a part of the government's high north policy (Anon., 2011a), and Arctic food production has benefitted from the government's increasing interest in local food, amongst other voiced in several reports to the Parliament (Anon., 2011b, 2015). The government in June 2019 announced that it would double its economic support to "Arctic agriculture" from 2 to 4 mill NOK annually (Anon., 2019). As such, the government is taking action to promote food production in the Arctic. Even though food security is not a pressing matter in Arctic Norway compared to some other Arctic areas, these initiatives contribute to the Norwegian government's fulfillment of the obligation to realise the UN Sustainable Development Goal \#2. In particular, providing knowledge, financial services and opportunities for value-adding of local food are important initiatives in a Norwegian Arctic context.

It is the Gulf Stream that allows agriculture production in Northern Norway. You will not find the same production on the same latitude in the other Arctic states. Even though the production is lower than further south (yield per acre), the unique climatic northern growth conditions with long days and low temperatures, provide some advantages for food and fodder products. For instance, broccoli contains more C-vitamin, while carrots and turnips get a sweeter taste, and the cloudberries get bigger (Johansen, Uleberg, \& Mølmann, 2018). The cold climate also gives very little diseases, and hence the use of pesticides and medicines is very low and animal welfare high (Johansen, Uleberg, \& Mølmann, 2018). Future climate changes also offer possibilities for northern horticulture production through prolonged growing seasons in Northern Norway. As for seafood, the most productive areas and biggest fishing grounds are in the north (in the Lofoten area and in the Barents Sea), and Nordland and Troms are the two biggest counties for aquaculture production and are still increasing. Primary processing is taking place in all three counties, while the number of secondary processing companies is decreasing as one moves northwards.

Primary processing includes slaughtering, sorting and cleaning, processing, and packing of a raw material product from primary production. It can 
also include adding some conservatives (salt and sugar), drying, freezing, etc. Secondary production is used to denote processing that significantly changes the product by adding other ingredients and produce a consumer-ready and value-added product (Elde et al., 2018). The differences in the number of secondary production companies are not surprising, given the much smaller population in the northernmost county, and hence also a smaller local market.

There are about 3,000 farmers in Northern Norway and 950 reindeer owners. In addition, about 2,000 persons are working in the processing industry. The agricultural processing industry in Norway is dominated by large cooperatives owned by the farmers, like TINE (dairy) and Nortura (meat). In addition, there are some other large companies and many small, local enterprises. The number of small companies in the agricultural sector has been increasing rapidly the last decades due to increasing demands for locally produced special food products (Norsk mat, 2018), and today there are about 500 local food producers in Northern Norway. ${ }^{1}$

As for fisheries, there are approximately 4,500 people directly employed in fishing and another 3-7,000 working in the fish processing industry throughout the year in Northern Norway. In aquaculture, 2,000 are employed in the main industry and 5,500 in supporting industries. Despite declining employment in the industry as a whole, production is higher than ever before. There are 100 landing stations/primary processing companies and 40 aquaculture companies. There are about 80 companies producing for the national market. The fisheries' catch varies considerably from year to year. In 2015, about 94,000 tons were landed in the north, which constitutes $42 \%$ of the total landings in Norway (SSB, 2016). About half of the production of farmed salmon is taking place in Northern Norway, with 517,000 tons in first-hand sales from Northern Norway in 2015. The economic significance of the farming industry, for Norway as a whole, by far exceeds the traditional fisheries. Only a small amount of Norwegian seafood goes to domestic consumption $(<5 \%)$. Still, Norway is self-sufficient in seafood, as well as in dairy products.

Despite growing importance for the economy and employment, food production in the Arctic region is associated with some challenges. Not only are the food producers faced with challenging environmental conditions, the region also suffers from poor and/or costly infrastructure, limited entrepreneurial capacity, relatively small local markets and long-distance to bigger markets. Most food producers in the Norwegian Arctic region are as mentioned small and micro-sized companies, with less than 5 employees. It is a known challenge for such small companies to manage all aspects of running a healthy company (Dawar \& Frost, 1999), and according to Statistics Norway approximately 70\% of SMEs fail within five years (SSB, 2019). Those who survive though, have a four time increase in the number of employees, proving the importance of these SMEs to rural Arctic communities (SMB Norge, 2018). 
Competence is the key to success. The government supports regional Centers of Expertise for local food production, where one center is covering the Arctic region. The aim is to build competence in small- and medium-sized local food producers and increase the value of the Arctic food. In addition, food producers have established various types of network corporations to overcome or mitigate some of the challenges of being a small producer. The networks are often partly publicly funded through Innovation Norway. Most networks are geographically linked (like Nordlandsmat or Vesterålsmat), while others are limited to a product type like Lofotlam (sheep meat) and Arktisk kje (goat meat). In addition to knowledge exchange and support, the main areas of cooperation are distribution, sales, and marketing (Natcher et al., 2019). There has been an initiative to develop a regional food label, "Northern Norwegian food label" (Nordnorsk Matmerke) (Nordnorsk Landbruksråd, 2018). The aim was to increase value creation through better visibility of Arctic food products in stores and give the products an advantage in the market. Originally, only the agricultural sector was involved, but it was a stated goal to include seafood from the region. The idea was to develop an area of origin label for products based on raw material and processed in the Norwegian Arctic region. Despite the lack of realisation of the label, so far, this shows that many actors in the sector have a belief in the branding of Arctic origin. Still, it does not seem to exist any thorough analysis neither of the use of Arctic origin in branding of food products or of which attributes or characteristics has the highest potential in branding of Arctic food.

\section{Research question and analytical approach}

Internationally there is increasing consumer interest in the origin of food, traceability, and in supporting local companies (Feldmann \& Hamm, 2015; Hingley, Boone, \& Haley, 2010). Especially for high-quality food products the use of regional origin is often successfully incorporated in the branding (Luceri et al., 2016; Trognon, 1998), conveying a message of authenticity and tradition (Ilbery \& Kneafsey, 1998) and health and sensor properties (Bryla, 2015). Displaying origin can, therefore, function as a risk reduction, reassuring consumers about where the products come from and how they have been produced (Luceri et al., 2016). In some cases, it can even replace the need for building a brand name (van Ittersum et al., 2003).

There is also an expressed desire to reduce the number of steps the food goes through from production to plate (Murtagh, 2015). It is in the context of this consumer interest and concern, and the governmental support one sees growth in the production of local food products. Several studies show consumers' preference for food from their own region, i.e. local food (see, for instance, Aprile, Caputo, \& Nayga, 2016; Feldmann \& Hamm, 2015; Ilbery, Morris, Buller, Maye, \& Kneafsey, 2005). Local food is getting increasingly important also for the Norwegian consumer, reflected in 
increasing sales numbers in the retail sector. In 2013, local foods had twice the increase in turnover compared to other food products. Norwegians also show an increased willingness to pay for food from their own region (Ipsos MMI, 2014). Local and regional foods however also have potential for distribution toward national consumers. Extending the local or regional market to a national market offers a larger segment of high-end customers with a high willingness to pay. The marketing strategy might, however, need to be different. If local food producers aim to extend their market outside their region, should the products be marketed the same way as in the local market? And should they brand their product based on origin toward consumers outside the region? To answer this, one needs to know how consumers outside the region perceive food from this region, compared to the local consumer.

Within marketing, branding, i.e. the marketing practice of creating a name, symbol or design or a combination of these that identifies and differentiates a product from other products, is one way to achieve higher willingness to pay, increase market penetration and/or develop new markets (Keller, 1998; Murphy, 1998). A successful brand is known to give better prices, more loyal consumers, and strengthen the company's reputation (Keller, 1998; Murphy, 1988). Even established companies can increase turnover and/or profit through small adjustments in how and what they communicate about their products and to whom. Branding is, however, expensive, time-consuming, and a risky process, and exploiting existing positive associations toward the product, company or region of origin could be beneficial. A brand is more than a name, and to create a value of a brand name a set of associations need to follow (Aaker, 1991). As shown by Trognon (1998), if a region already is perceived positively based on subjective associations, these associations might be successfully used as part of the branding if they are transferable to the regional product. A regional product is defined as a product whose quality and/or fame can be attributed to its region of origin and which is marketed using the name of the region of origin (van Ittersum et al., 2003). Examples of products marketed as regional specialties are abundant, like Parma ham, Champagne, and Florida Oranges. The regional image can have an influence on how the product is perceived, and according to van Ittersum et al. (2003) the place of origin can also have very little or even a negative influence on the evaluation of the product. To avoid this, it is eminent that the particular product is perceived as authentic for the region and that the consumers should perceive the region to be suited for production of the product (Kuznesof et al., 1997; van Ittersum et al., 2003. The qualities associated with these products may or may not be scientifically documented, like more vitamins, sweeter, etc. (Johansen, Uleberg, \& Mølmann, 2018).

The question raised here is therefore, whether and how can the Arctic origin be used to create a higher perceived value for consumers in the Arctic region and in a national market? From this follows two groups of questions: (1) What do consumers perceive as authentic "Arctic food"? What are the characteristics of Arctic food? And is there a difference in these perceptions 
between consumers living in or outside the Arctic region? (2) Based on the above, is there a potential for promoting food from the Arctic more effectively by utilising certain characteristics, in the region and outside the region, and for different food products? What are the producers doing today, and is there a potential for increased value creation by adapting marketing communication? Arctic food is defined as food based on raw materials from the Arctic which is also being processed in the Arctic region.

\section{Material and methods}

A survey was conducted of 472 consumers, 246 in Arctic Norway and 226 in Southern Norway, in the area around the capital. The consumers were all more than 18 years of age. The aim was to reveal what type of food consumers think of as Arctic food and what qualities they ascribe to Arctic food. By having respondents both within and outside the Arctic region, we would be able to test our assumption about different perceptions of Artic food between those living in the Arctic region and consumers in the south. Attaining knowledge about how consumers perceive food originating from their own region (local Arctic food) compared to consumers living outside of the region (Arctic food), will provide producers with important knowledge about Arctic origin as a marketing opportunity in the differed markets.

The survey first had a section aiming to capture association about species and characteristics. This part started with an open-ended question, followed by closed questions. This is to make sure also the consumers' own thoughts are captured without any influence from the survey's predetermined characteristics (Altintzoglou, Sone, Voldnes, Nøstvold, \& SognGrundvåg, 2018). In the open question, the consumers were asked to state what were the three first words that came to mind when thinking about Arctic food. In the closed questions the consumers were asked to state how much they associated predefined factors to food from the Arctic region. The scale was running from 1 to 7 , where 1 was denoting "not at all" and 7 "very much." Brands of the Arctic food products for sale in the Tromsø groceries and specialist stores were used to identify relevant factors.

A similar survey was developed targeting food producers in Arctic Norway. The survey was sent to 86 companies, of which 29 companies responded. The aim of this survey was to gather information about how the producers market their products, what they think are their main selling points, and to see if these correspond to the consumers' perception of Arctic food. The producers were also asked an open question first; "What words would you use for marketing the Arctic origin of your food products?" They were then asked, "Do you use any of the following words in your marketing" and were asked to rate their answers from 1 "not at all" to 7 "to a large degree." The words were based on the same information as the consumer factors.

The rank order of importance of factors that describe and add value to Arctic food was tested using Friedman's related samples test (a Shapiro-Wilk 
test showed that normality was violated). Differences in importance between individual factors were determined using Wilcoxon related samples test for pairwise comparison.

\section{Findings: Consumer perceptions, producer perceptions, and the Arctic food marketing}

In the following first the results from the consumer study are presented followed by the results from the producer survey. The results will then be discussed in the next chapter.

\section{What is the Arctic food-species and characteristics from the consumer perspective?}

The survey started with an open question, asking the consumers to state three words that describe what they associate with Arctic food. Some chose to describe species, some wrote different characteristics, and some both. More than 900 different words were given. The words were sorted, categorised (species or characteristics), and translated. Some choices were made when sorting a word into "species" or "characteristics," for instance "reindeer meat," "reindeer steak," and "reindeer" were all translated into "reindeer" as a species. When a specific traditional dish was stated, for instance "boknafisk" (cured cod), it was translated and categorised as a characteristic of Arctic food and not categorised under the main ingredient species (in this case cod). The reason for this is that typical traditional dishes and food preparation is more related to culinary heritage and tradition than species.

The species "berries" consists of several types of berries. Cloudberries were mentioned the most. Also, lingonberries and blueberries were mentioned. As they all are wild berries, they were generalised into "berries." Two respondents mentioned strawberries, but these were not included as they are cultured. Words like flavor, flavorful, rich flavor, tastes good, jummy, and good taste have all been included in the characteristic "tasty." And as mentioned, specific traditional dishes and types of cooking like tørrfisk (dried cod or other whitefish), lutefisk (dried whitefish treated with lye), klippfish (salted and dried whitefish), biljo (a specific reindeer stew/soup) and the generalisation "traditional food" have all been included in the characteristic "tradition."

For the respondents in Northern Norway, we see that the species "reindeer" is most stated (100) when thinking about Arctic food. With the exception of "berries" (45), four types of seafood; "fish" (81), "cod" (49), "king crab" (32), and "salmon" (23) are the species most stated after "reindeer," as illustrated in the word cloud in Figure 11.3.

The respondents in the South of Norway clearly state "fish" (110) the most, while "reindeer" comes second (60). As in Northern Norway, "Cod" 


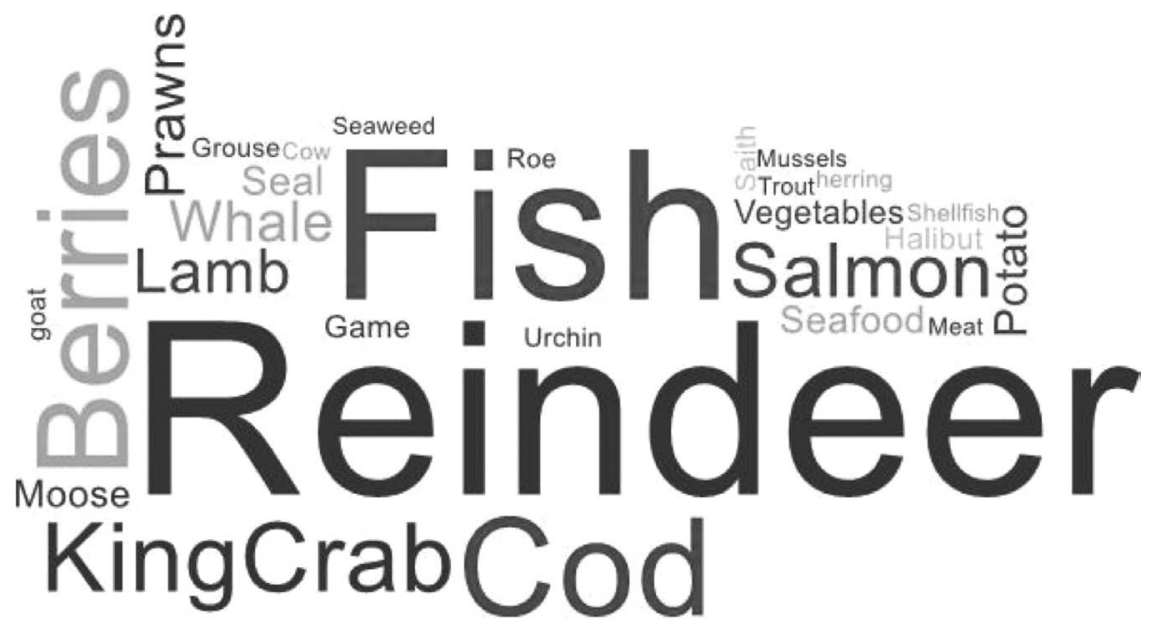

Figure 11.3 Species suggested by Northern consumers.

(71) and "King crab" (60) are the seafood species most stated. "Berries" (all types of wild berries) (28) are the fifth most mentioned, while "salmon" (22) comes sixth, as illustrated in Figure 11.4.

The consumers who rather thought of quality characteristics when thinking about Arctic food gave a wide range of descriptions. More

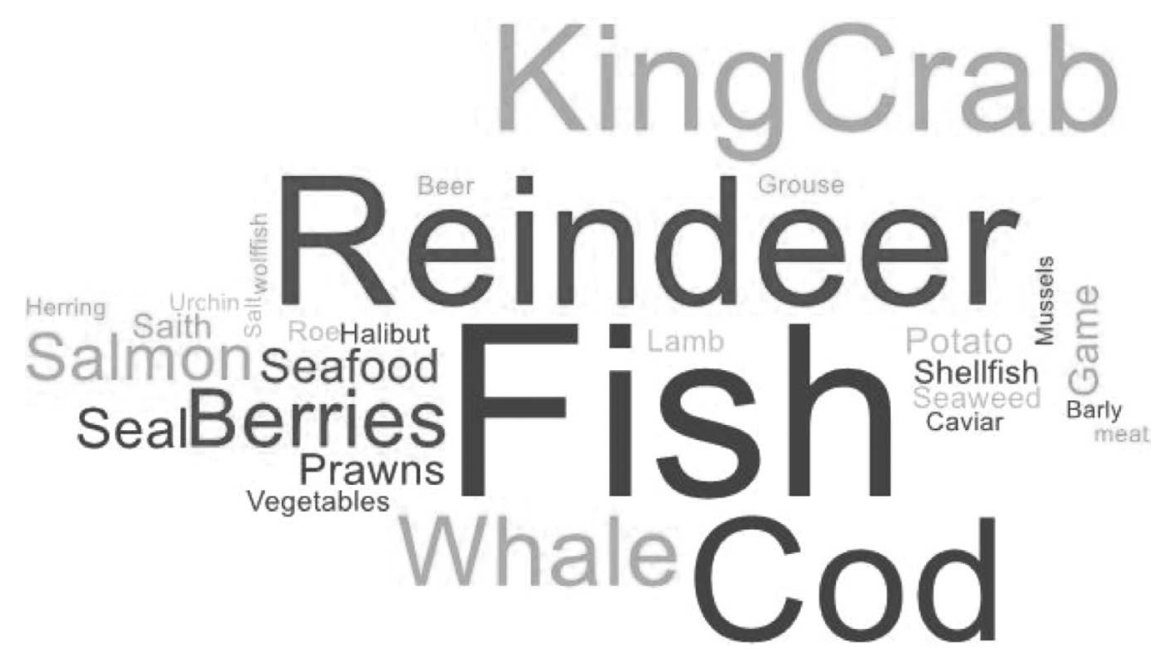

Figure 11.4 Species suggested by Southern consumers. 

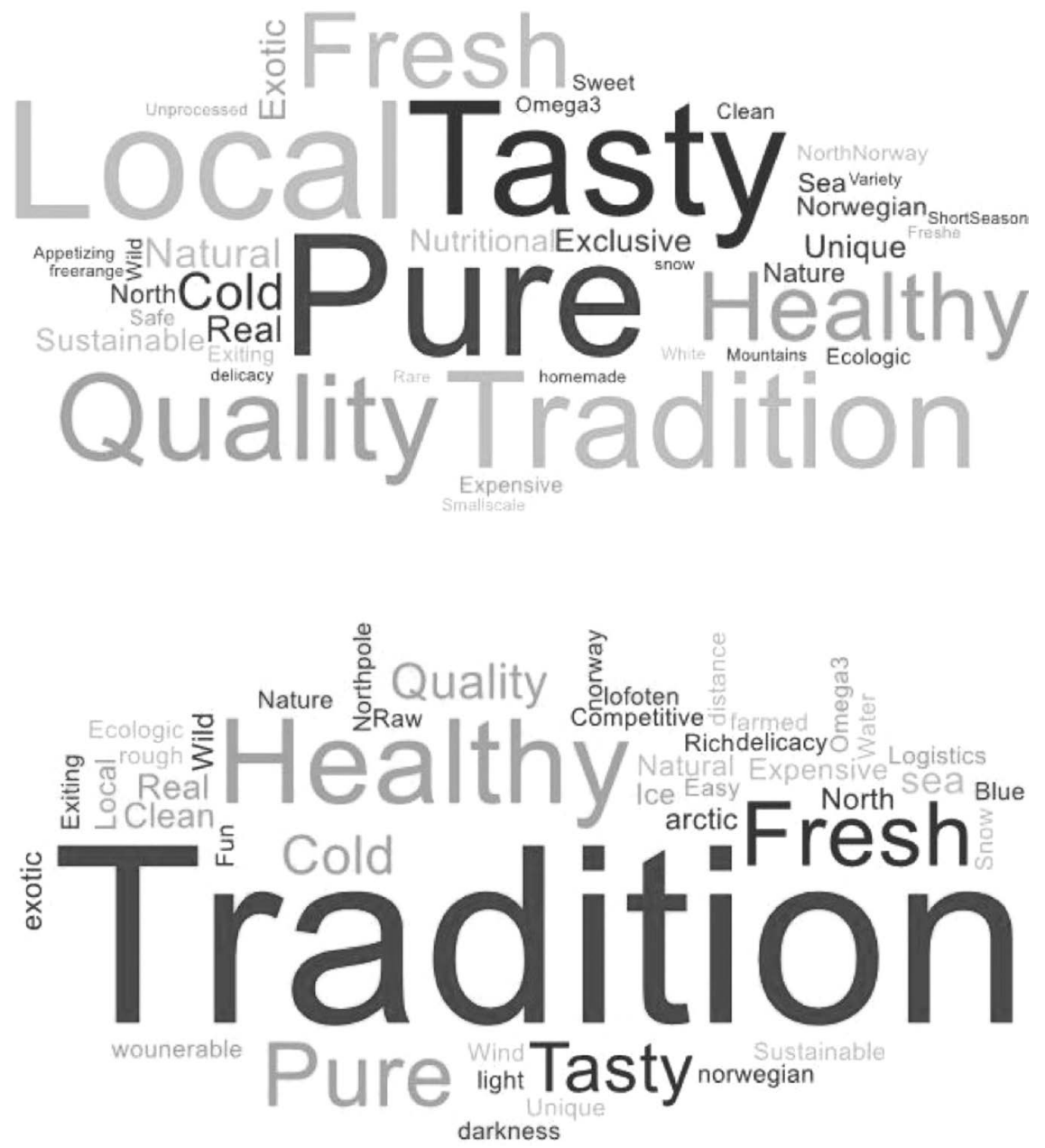

Figure 11.5 Quality characteristics mentioned by Northern and Southern consumers.

than 130 different words were used. Sorted, categorised, and translated, Figure 11.5 shows the main characteristics identified by the northern and southern respondents, respectively.

The results show that consumers mainly think of different seafood species as Arctic, this range from cod, whale, and saith to seaweed and urchin (in total 600). Terrestrial species can be grouped into two; farmed and wild. Reindeer, game and wild berries are mentioned more often (a total of 266) than farmed vegetables (26) and animals (24). This applies to both northern and southern consumers.

For the northern consumers the characteristics "pure" (32), "local" (31) and "tasty" (30) were mentioned the most. "Tradition" (25), "quality" (22) 


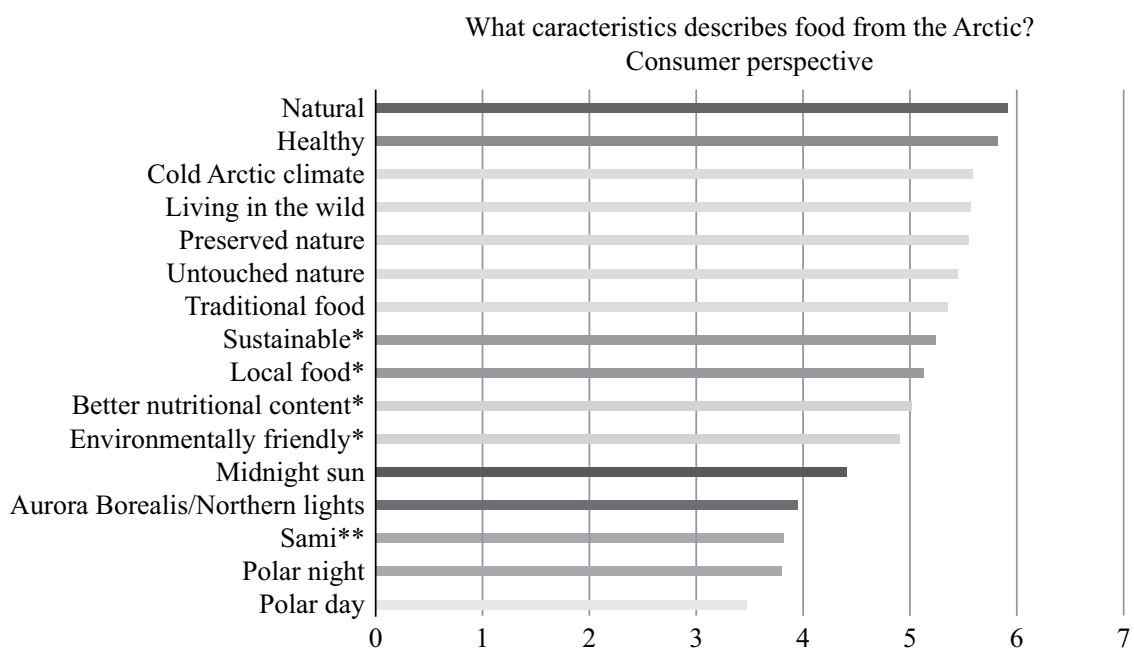

Figure 11.6 What characteristics describe food from the Arctic? Consumers' perspective.

and "fresh" (20) were also frequently used. For the southern consumers "tradition" (46) was by far the most mentioned characteristics, both the word tradition itself and description of traditional cooking and traditional dishes. "Healthy" (20) was the second most mentioned characteristic, followed by "fresh" (14) and "pure" (14).

In the next part of the survey, the consumers were asked to think about food from the Arctic and then rate different characteristics for how much they associate them with Arctic food (Figure 11.6). Different colors and nuance of color indicate significant differences between traits so that the dark green, lighter green and pale green are significantly different. The characteristics are then grouped into three groups; green, blue and, red where green is considered to be the most important factor, blue medium importance, and red considered a group of not important factors.

The analysis shows that the characteristics the consumers mostly use to describe food from the Arctic are "natural," followed by "healthy." "Cold Arctic climate," "living in the wild," "preserved nature," "untouched nature," and "traditional food" are all in the group of the third most associated characteristics of food from the Arctic. "Traditional food," the characteristics that scored the highest in the open question also scores high in the rating. Being pale green, it is in the third strongest group of associations with Arctic food.

The data was split between the responses from the Northern and Southern consumers. The consumers in Northern Norway gave a significantly higher score to "local food," "environmentally friendly," "sustainability," and "better nutritional qualities." These factors are marked 
with * in Figure 11.6. The respondents from Southern Norway associate the characteristic "Sami" more to Arctic food than do the northerners, marked with $* *$ in Figure 11.6. Otherwise the factors were not significantly different, meaning the factors were rated with equal importance between north and south.

\section{Producer perspective-what characterises the Arctic food}

The producer respondents were all SMEs with less than 20 employees and turnover lower than 40 mill NOK, and $50 \%$ had less than 5 mill NOK in turnover. 19 of the 29 companies were selling within the Arctic region, and 10 of these had their sole market here, while one also sells nationwide and two moves from their regional market directly on to export. Only four companies sell both within- and outside the region and exports. 15 of the companies have their main market within Norway, but outside the Arctic region, three of these also export their products. When asked to rate their major challenges, market-related issues were chosen by 18 companies.

Parallel to the question to the consumer about what they perceive as characteristic of Arctic food, the producers were asked in an open question which characteristics they would use to promote their products. As shown in the word cloud (Figure 11.7), "pure" (25), "Arctic" (23), "flavor" (23), and "natural" (19) are the words used the most. Within "flavor" words like "flavorful," "strong flavor," "nice flavors," and "natural flavors" are all included. A wide variety of words describing the nature where the products are grown or raised are used by several producers, like "the fish lives in pure cold waters" or "luscious grassland with natural herbs and an eternal spring under snow-covered mountains."

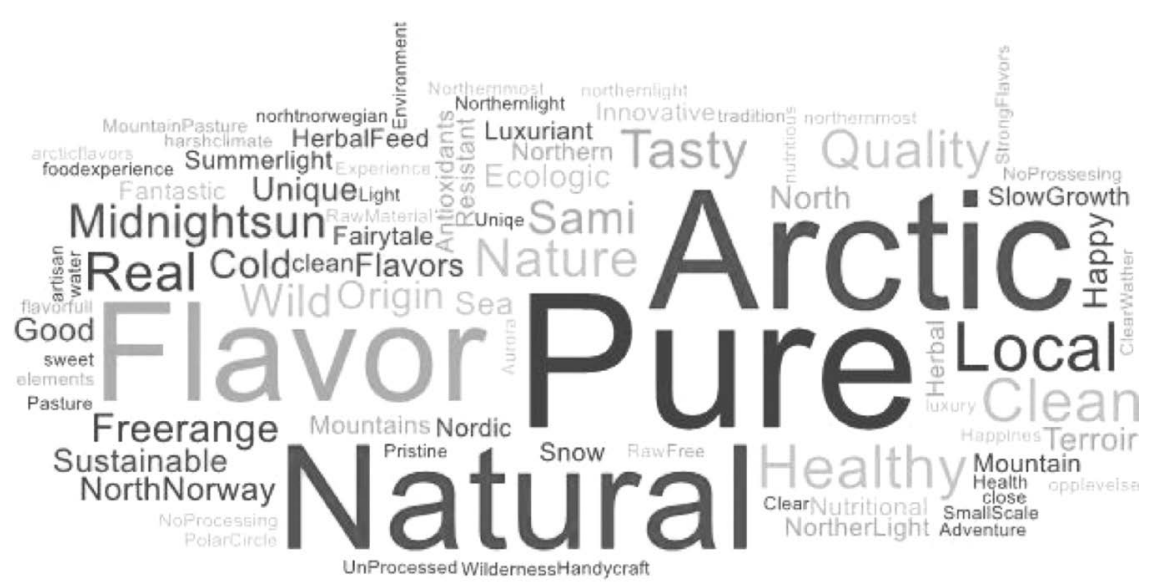

Figure 11.7 Producers' choice of characteristics in communication of their products. 


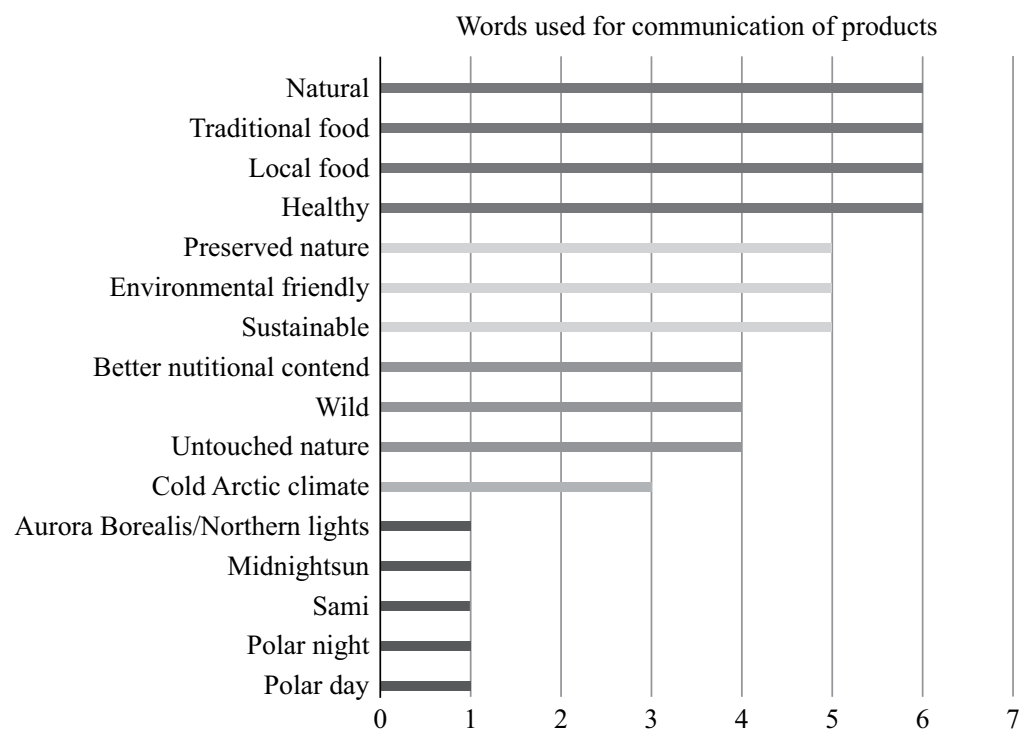

Figure 11.8 Words used for communication of products.

For the producers, the open question was followed by closed questions where they were asked to rate to what extent they used different words in communicating about their own products. The results are presented using a median because the producers are very polarised in their answers. The answers are not checked for significance due to the low number of respondents. Figure 11.8 presents the scores where the different colors represent the median scores for the factors. The group that is used the most includes the words "natural," "traditional," "local," and "healthy." It must be mentioned that the closed question in the questionnaire did not include "z," "Arctic origin," and "purity of taste." There was no difference in the choice of words between producers aiming for regional or national markets. Between the open and closed questions tradition and healthy are hardly mentioned in the open question but gains a high score in the closed question.

\section{Discussion}

The question raised in this study is whether there is a potential for adding value by exploiting the regional origin in the marketing of food products from the Arctic, within and outside the region. Where one expected to find many differences between perceptions of northern and southern consumers, results show a high degree of correspondence. Below the similarities and differences will be further explored, starting with the consumer dimension, followed by the consumer-producer dimension. 


\section{The consumers and the North-South dimension}

Recalling the findings from van Ittersum, Candel, and Meulenberg (2003) and Trognon (1998) that for region of origin branding to be successful, there has to be correspondence between the product and its qualities and the consumer's perception of the region, the survey set out to identify what consumers perceive as authentic for the Arctic region. The results showed a high degree of consistency between the consumers in Arctic Norway and outside. The open questions to let the consumer state what is on the top of their mind when asked what they associate with Arctic food, show that some think of species while others first and foremost think of qualities. Different types of seafood and reindeer are by both northern and southern consumers considered to be the most "Arctic" food products. This is not surprising, as the majority of reindeer herding is taking place in the northernmost region, and the major seasonal fisheries are taking place in the north, like the Skrei fisheries (breeding cod) and the fall saith fisheries. Branding such species or products of these species as Arctic products might, therefore, add value to the product. More surprisingly is it maybe that King crab seems to have thoroughly established itself as an Arctic species in the mind of the Norwegian consumers, both in the north and in the south. King crab is an Arctic crab species, but it is a relatively new species in Norway, first being commercially harvested in the early 2000 s. This illustrates that it is not only traditional species or products that can be marketed as Arctic and that it is possible for new species and products to be established as Arctic. For instance, the more exotic species like urchin and seaweed, which were mentioned by a few consumers, may have potential as "Arctic food products" in the future.

Besides reindeer and seafood, berries were among the top five species mentioned, both in the north and south. Thus, it seems that wild-caught, harvested and gathered products that are perceived to be "wild" is more authentic Arctic food than agricultural products like potatoes, vegetables, and farmed animals. This despite efforts being done within collective branding of the origin of such species, for instance Målselvnepe (turnip from Målselv), Lofotlam (lamb from Lofoten).

When it comes to qualities, the northern consumers have strong associations with "purity," "taste" (always in a positive sense), "high quality," and "health." The southern consumers to a large degree mention the same characteristics, but here "traditional food production or dishes" are mentioned the most. Most of the characteristics are corresponding with current food trends focusing on health-related qualities; less processing, purity of production, purity of flavor, and no additives (Asioli et al., 2017). For the producers in Arctic Norway, the bias toward traditional dishes or methods can be both positive and negative, depending on what type of products they want to promote. The study indicates that a highly modern and/or novel product should maybe not be branded as an Arctic product. The food trend 
of convenience is apparently not put in context with Arctic food, and if a producer should use Arctic origin in the branding of such a product it might only be successfully applied if the raw material used in the product is associated with Arctic food (i.e. some type of ready meal based on reindeer). On the other hand, this also might mean a higher acceptance for products that are not so convenient.

It is interesting that favorable taste (sweet berries, pure seafood, and strong and rich taste) are amongst the first thoughts in the mind of the consumer, both in the south and the north. Elements of taste were not included in the part where the consumer was to rate different set qualities because this was not identified in the marketing of the products in shop that were used as a basis for the survey. In the set qualities characteristics related to nature and the environment came out strong. It seems that food production in the Arctic is considered to take place on the terms of nature (being untouched, preserved, wild and natural). These aspects could also be connected to health, as a clean and natural production often is considered using fewer preservatives, fewer additives, etc. Within these most important characteristics, there is no difference between perception in the south and in the north. This implies that a stronger focus on healthy and natural aspect could be a useful marketing strategy, both regionally and nationally.

The survey shows that the consumers in the north to a much higher degree think food from their own region is more "sustainable," more "environmentally friendly" and has "better nutritional content." This could be used more actively by producers aiming for a regional consumer. The potential of exploiting documented better nutritional content or more favorable taste should be utilised. In general, the results indicate that it is not necessary to develop a different branding strategy for the southern and northern markets. Though, if you are including less important elements like better nutritional content or sustainability when communicating about your product this will resonate more with the northern consumers. Commonly used phrases like "grown under the midnight sun" or "the northern lights" are generally not considered to ascribe value neither for northern nor southern consumers. One could assume that this would resonate more with foreign tourists and such phrases are observed on many food products that seem to be targeting tourists in the region. Using such characteristics might however result in the product losing out on local customers. Whether it fits the expectations of tourists and to what degree national customers disregard these products remains to be studied.

Luceri et al.'s (2016) argument is that emphasising the geographic origin of a product has a positive effect on consumers because it ensures authenticity, quality, and food safety. The survey shows that consumers, both in northern and southern Norway have associations of especially quality and food safety to food from the Arctic. In the open-ended questions pure, "healthy" and "fresh" are dominating. In the closed-ended question "health" and "natural" are significantly higher rated than other characteristics. The 
results indicate that not only does the Arctic origin give the assurance about food safety (natural and fresh) as emphasised by Luceri, Latusi, and Zerbini (2016), it also incorporates several health-related elements (pure, clean, and fresh) that is important according to Bryla (2015). Finally, the Arctic origin includes authenticity and traditional elements (tradition and real), characteristics identified by Ilbery and Kneafsey (1998) to be important. This shows that food from the Arctic has high potential for benefitting on Arctic origin branding.

\section{The consumer - producer dimension}

In the open-ended question, the producers taking part in the survey list natural, flavor, pure and healthy as the characteristics they would use in communication of their own food products. The closed question also enhances the importance of tradition and environmental concerns, like preserving nature, environmentally friendly and sustainability. Natural, tradition and healthy corresponds with the most chosen criteria by the consumers. Traditional was specially mentioned in the south. This shows that the producers to a high degree understand and do take advantage of the Arctic origin of their products by using words that resonate with that of the consumers. It might, however, seem that the producers are less aware of the potential in exploiting the associations to the wild, cold Arctic climate and untouched nature in their branding. This might be because the producers in the survey do not think that their products are based on such "wild material." But it might also be that the producers are unaware of the strong association the consumer has between food from the Arctic and the nature associated with the Arctic region. For instance, reindeer producers might focus on their natural and traditional production rather than the association to a (more or less) wild animal, the wild nature where they live, and the cold Arctic climate creating this nature, and hence product. The producers and consumers give the same rating to the elements like midnight sun, northern lights and polar night. These are not very important when it comes either to association or communication of Arctic food.

\section{Conclusion}

The study has explored Arctic origin as a marketing opportunity for food producers in Arctic Norway. The assumption was that it is possible to achieve added value based on Arctic origin in strategic marketing, but that to do this, it is vital to know what consumers perceive as Arctic qualities. The study finds a high correspondence between northern and southern consumers on what they associate with the Arctic food products both in regard to species; reindeer, seafood, and game, and in regard of characteristics; natural, pure, healthy, tasty, and traditions. This means that a producer often can use the same strategy in their communication with their northern 
and southern customers. They can also extend their markets, from regional to national without extensive change in their branding, unless they have a strong focus on a local food image.

Another important finding is that many of the characteristics associated with Arctic food are in line with current international food trends, like health, natural, authenticity, and tradition. Within these associations, we, therefore, see many opportunities for branding products based on their Arctic origin. The associations of the Arctic as something wild, pure, and untouched, thus using "Made in the Arctic" in strategic marketing would correspond with these traits.

\section{Acknowledgment}

This work is part of the Arctic Council project "Arctic as a Food Producing Region" and the Norwegian part has been supported by the Norwegian Ministry of Foreign Affairs through the Arktis2030 programme, project number NOR15/0117.

\section{Note}

1. Numbers from The Centre of Expertise for local food production North (Kompetansenettverket for lokal mat Nord).

\section{References}

Aaker, D. (1991). The Negative Attraction Effect? a Study of the Attraction Effect Under Judgment and Choice. NA - Advances in Consumer Research, 18, eds. Rebecca H. Holman and Michael R. Solomon, Provo, UT: Association for Consumer Research, 462-469.

Altintzoglou, T., Sone, I., Voldnes, G., Nøstvold, B., \& Sogn-Grundvåg, G. (2018). Hybrid surveys: A method for the effective use of open-ended questions in quantitative food choice surveys. Journal of International Food \& Agribusiness Marketing, 30(1), 49-60. doi: 10.1080/08974438.2017.1382422.

Anon. (2011a). Report to the Parliament no. 7 (2011-2012). The High North (Nordområdene), Oslo, November 2011.

Anon. (2011b). Report to the Parliament no. 9 (2011-2012) Welcome to the table (Velkommen til bords), Oslo, December 2011.

Anon. (2015). Report to the Parliament no. 31 (2014-2015) The farm as a resource - the market as the goal (Garden som ressurs - marknaden som mål), Oslo, June 2015.

Anon. (2016). Report to the Parliament no. 11 (2016-2017) Change and Development. A future-oriented agricultural production (Endring og utvikling. En fremtidsrettet jordbruksproduksjon), Oslo, December 2016.

Anon. (2019). Vil produsere mer mat i Nord-Norge https://www.regjeringen.no/no/ aktuelt/vil-produsere-mer-mat-i-nord-norge/id2662274/. Dato: 28.06.2019

Aprile, M. C., Caputo, V., \& Nayga, R. M. (2016). Consumers' preferences and attitudes toward local food products. Journal of Food Products Marketing, 22(1), 19-42. 
Asioli, D., Aschemann-Witzel, J., Caputo, V., Vecchio, R., Annunziata, A., Næs, T., \& Varela, P. (2017). Making sense of the "clean label" trends: A review of consumer food choice behavior and discussion of industry implications. Food Research International, 99, 58-71.

Bryla, P. (2015). The role of appeals to tradition in origin food marketing: A survey among Polish consumers. Appetite, 91, 302-310.

Dawar, N., \& Frost, T. (1999). Competing with giants: Survival strategies for local companies in emerging markets. Harvard Business Review, 77, 119-132.

EC. (2016). User Guide to the SME definition. European Commission (Ref. Ares (2016) 956541 -24/02/2016). European Union. https://ec.europa.eu/regional_policy/ sources/conferences/state-aid/sme/smedefinitionguide_en.pdf

Elde, S., Kvalvik, I., Nøstvold, B., Rødbotten, R., Dalmannsdottir, S., Halland, H. ... Sidorova, D. (2018). The Arctic as a food producing region. Phase 1: Current status in five Arctic countries (Nofima Report 10/2018). Nofima AS.

Feldmann, C., \& Hamm, U. (2015). Consumers' perceptions and preferences for local food: A review. Food Quality and Preference, 40, 152-164.

Hingley, M., Boone, J., \& Haley, S. (2010). Local food marketing as a development opportunity for small UK agri-food businesses. International Journal on Food System Dynamics, 1(1012-2016-81180), 194-203.

Ilbery, B., \& Kneafsey, M. (1998). Product and place: Promotion quality products and services in the lagging rural regions of the European Union. European Urban and Regional Studies, (5), 329-341

Ilbery, B., Morris, C., Buller, H., Maye, D., \& Kneafsey, M. (2005). Product, process and place: An examination of food marketing and labelling schemes in Europe and North America. European Urban and Regional Studies, 12(2), 116-132.

Iversen, A., Hermansen, Ø, Henriksen, E., Isaksen, J. R., Holm, P., Bendiksen, B. I. ... Dreyer, B. (2016). Fisken og folket (A. Iversen, Ed.). Orkana.

Johansen, T. J., Uleberg, A. L., \& Mølmann, E., J. (2018). Arktisk kvalitet - En beskrivelse av nordlige natur- og klimaforhold og virkning på egenskaper hos nordnorske matprodukter. NIBIO RAPPORT 4 (40).

Ipsos, M. M. I. (2014). Norske Spisefakta 2014.

Keller, K. L. (1998). Strategic brand management, building, measuring and managing brand equity. Prentice Hall, Inc.

Kuznesof, S., Tregear, A., \& Moxey, A. (1997). Regional foods: A consumer perspective. British Food Journal, 99(6), 199-206.

Luceri, B., Latusi, S., \& Zerbini, C. (2016). Product versus region of origin: Which wins in consumer persuasion? British Food Journal, 118(9), 2157-2170. doi: https:// doi.org/10.1108/BFJ-01-2016-0035.

Murphy, J. (1998) What is branding? In "Brands, the new wealth creator”. MacMillian press.

Murtagh, A. (2015). The defining characteristics of alternative food initiatives in Ireland: a social movement battling for an alternative food future? [PhD Thesis, University College Cork].

Natcher, D., Yang, Y., Hobbs, J., Hansen, K., Govaerts, F., Elde, S. ... Valsdóttir, P (2019). The Arctic as a Food Producing Region. Sustainable Development Working Group, Arctic Council.

Nordnorsk Landbruksråd. (2018). Nordnorsk matmerke. Stolt Arktisk Bonde. https:// arktisklandbruk.no/wp-content/uploads/2019/03/Rapport_2018_ORG.pdf 
Norsk mat. (2018). Salg av lokal mat og drikke i dagligvarehandelen. Norsk mat. https://norskmat.no/no/norsk-mat-i-tall.

SSB. (2016). 08868: Fangst, etter fiskefartøyet sin landingskommune og hovedgruppe av fangstarter [Metadata]. https://www.ssb.no/statbank/table/08868?rxid=9f2fb50efd24-48b0-908f-76f 1c88e4915

SSB. (2019). Nyetablerte foretaks overlevelse og vekst [Data set]. https://www.ssb. no/fordem

SMB Norge. (2018, August 8). Hvorfor mislykkes så mange små bedrifter?. SMB Norge. https://www.dinbedrift.no/slik-lykkes-du/

Trognon, L. (1998). The influences of territorial identity on consumer preferences: A contribution based on the RIPPLE programme. Consumer preferences for Products of Own Region/Country and Consequences for Food Marketing. AIRCAT Workshop Proceedings, 4 (3).

van Ittersum, K., Candel, M. J., \& Meulenberg, M. T. (2003). The influence of the image of a product's region of origin on product evaluation. Journal of Business Research, 56(3), 215-226. 